\title{
Kalevalat, joita ei koottukaan kansanrunoudesta
}

\author{
Eepoksen syntyhistorian muokkaaminen 2000-luvun muunnelmaromaanien \\ tarinamaailmoissa
}

\author{
Elli-Mari Ahola
}

$\mathrm{T}$ arkastelen artikkelissani 2000-luvun Kalevala-muunnelmaromaaneja. Ne ovat kertomuksia, jotka toisintavat eri laajuudessa Kalevalan (1849) tapahtumia ja henkilöitä tai vähintään tarjoavat maailman, jossa Kalevala olisi voinut tapahtua. Muunnelmien produktiivisuus on nähty osana yhä jatkuvaa Kalevala-prosessia, joka lähtee kansanrunoudesta ja Lönnrotin Kalevalan koostamistyöstä (ks. esim. Knuuttila, Laaksonen, Piela 2008, ix). Eepos ymmärretään nykyään nimenomaisesti Lönnrotin taideteoksena, ja kuten Satu Apo (2004, 273) on todennut, harvaa asiaa on selvitetty niin perusteellisesti kuin Lönnrotin Kalevalan työstämisen prosessia. Muun muassa Väinö Kaukosen (ks. esim. 1956; 1979) elämäntyön perusteella on tiedossa Kalevalan säkeiden suhde kansanperinneaineistoon, joka Lönnrotilla oli käytettävissä (Siikala 2012, 37). Sen sijaan Kalevalan vaikutusta ympäröivään kirjallisuuteen 2000-luvulla on kyllä kartoitettu (Korpua 2017; Sallamaa 2010), mutta tarkastelu on painottunut Kalevala-yhteyden tunnistamiseen ja Kalevala-vaikutteisten teosten luettelointiin. Narratologisen kirjallisuustieteen välineistöllä on mahdollista avata tarkemmin yksittäisten Kalevala-muunnelmaromaanien rakentumista suhteessa Kalevalan maailmaan ja muihin maailmoihin.

Kalevala on tärkeä osa suomalaista kulttuurista muistia (ks. esim. Kaljundi, Laanes ja Pikkanen 2015, 31), ja myös Kalevala-muunnelmat muokkaavat sitä (Mäkelä 2021). Yksi 2000luvun Kalevala-muunnelmien vakiopiirre on, että ne tuovat fiktion keinoin Kalevalan tavalla tai toisella lähelle kirjoittamisaikansa maailmaa (Ahola 2020, 162). Kalevala-muunnelmissa muuntelun kohteena eivät ole pelkästään Kalevalan tapahtumat, vaan myös tietämys Kalevalan ulkopuolisesta kontekstista, kuten eepoksen pohjana olevasta kansanrunoudesta, joka niin ikään on osa kulttuurista muistia. Kalevala on pitkään ollut osa suomalaisten koulujen opetusta, ympäröivä yhteiskunta on täynnä viitteitä siihen esimerkiksi paikanniminä ja tutkittua tietoa on tavoitteellisesti tuotu laajasti saataville ja tuodaan yhä, mistä on osoituksena esimerkiksi Avoin Kalevala -editio, jonka kolmas osa ilmestyi vastikään (2021). Kalevala-muunnelmaromaaneissa kansanrunousaines ei välttämättä ole lainaamisen ja muuntelun kohteena, jollaisesta käytöstä löytyy esimerkkejä suomalaisesta nykyrunoudesta (ks. Gottelier 2020). Pikemminkin kansanrunous ilmiönä sepitetään toiseksi sen kontekstia muuntelemalla. Muunnelmat taustoittavat Kalevalan toisin omissa tarinamaailmoissaan. Eepoksen 
synty selitetään niissä fiktiivisesti uudelleen joko fantastisessa, historiallisessa tai nykyajan kaltaisessa tarinamaailmassa useimmiten siten, että kansanrunouden rooli Kalevalan syntyhistoriassa korvataan fiktiivisillä faktoilla. Tarinamaailma on rakennettu ottamalla mukaan joitakin lukijalle tutun maailman lainalaisuuksia, mutta Kalevalan syntytapaa kuvaava tieto eroaa lukijalle omasta maailmastaan tutusta Kalevalan syntytiedosta ja on fiktiivisessä tarinamaailmassa omaperäistä - fiktiivisen maailman rakentamisen kannalta kuitenkin todellista ja oleellista tietoa, fiktiivistä faktaa, joka koskee tarinamaailmaa, mutta ei sen ulkopuolista maailmaa. Muuntelun kohteeksi joutuessaan Kalevalan todellinen syntyprosessi samalla korostuu.

Tarkastelen tässä artikkelissa kansanrunouden korvautumista fiktiivisillä faktoilla 2000-luvun Kalevala-muunnelmaromaaneissa ja osoitan, että ilmiössä on kyse kaunokirjallisesta maailmanrakentamisen strategiasta, jolla toisaalta luodaan erilaisia uusia fiktiivisiä maailmoja intertekstuaalista aineistoa, tässä tapauksessa Kalevalaa ja sen syntykontekstia muuntelemalla, ja jolla toisaalta samalla sitoutetaan vastaanottaja alkuperäiseen aineistoon. Käytän esimerkkiteoksina kolmea Kalevala-muunnelmaromaania, joiden maailmat ovat keskenään erityyppisiä, mutta joita yhdistää se, että ne kaikki selittävät Kalevalan synnyn uudelleen korvaamalla historiallisen kansanrunouden omilla fiktiivisillä faktoillaan. Yhden tarinamaailma on esitetty fantastisena, toisen historiallisena ja kolmannen nykymaailman kaltaisena. ${ }^{1}$ Koska teokset edustavat niin historiallista kuin fantastista kirjallisuutta, tarkastelen niiden keinoja kiinnittyä oletetun lukijan todellisuuteen sekä fantasian ja maailmanrakentamisen teorioiden (Roine 2016; Polvinen 2012; 2018; McHale 2018) että historiallisen romaanin, tarkemmin erityisesti historiografisen metafiktion (Hatavara 2010; 2012; 2014; Hutcheon 1988; 2014), teorioiden näkökulmasta. Realistista historiallista fiktiota ja fantasiamaailmoihin sijoittuvaa fiktiota on tyypillisesti pidetty ellei suorastaan vastakkaisina niin ainakin merkittävän erilaisina kirjallisuuden lajeina. Kalevala-muunnelmien tapa kiinnittää fiktiivinen tarinamaailma lukijan maailmaan vaikuttaa kuitenkin toistuvan riippumatta siitä, onko teksti realistinen vai fantastinen, mikä puoltaa kummallekin lajille ominaisesti soveltuvan teoriakentän hyödyntämistä yhdessä.

Tarkasteltavat teokset ovat Harri V. Hietikon fantasiadekkari Roger Repo ja tuonen väki (2005), jonka maailmarakenteessa on hahmotettavissa muun muassa yliluonnollinen Kalevalan maailma. Toinen teos on J. P. Koskisen Kalevanpoikien kronikka (2018), jossa Kalevalan tapahtumat sijoittuvat historiallisena esitettyyn maailmaan. Kolmas analysoitava teos on Johanna Sinisalon Sankarit (2003), joka kirjailijan itsensä mukaan muistuttaa lajiltaan maagista realismia (Sinisalo 2004, 31). Tämä teos sijoittaa Kalevalan tapahtumat nykymaailmaamme muistuttavaan tarinamaailmaan.

\section{Tarinamaailma ja Kalevalan maailma}

Ennen kuin on mahdollista syventyä Kalevalan rooliin Kalevala-muunnelmien maailman osana, on syytä määritellä tämän artikkelin käsitys kaunokirjallisuuden maailmoista. Fiktiivisen tarinamaailman määritelmät sisältävät tyypillisesti ajatuksen, että tekstin perusteella

1 Olen aiemmin (Ahola 2020) esittänyt 2000-luvun Kalevala-muunnelmaromaaneista jaottelun kahteen eri tyyppiin sen mukaan, kuinka Kalevala-ainekset ovat niiden maailmassa järjestyneet. Nämä kategoriat pohjautuvat fantasiakirjallisuuden luonnollista ja yliluonnollista maailmaa jaottelevaan Maria Nikolajevan (1988) sekundaarimaailmateoriaan sillä erotuksella, että intertekstuaalisen sekundaarimaailman tunnusmerkkinä toimivan elementin ei välttämättä tarvitse olla yliluonnollinen, vaan riittää, että se on intertekstuaalinen, kalevalainen. 
syntyy tarinamaailma, jossa sijaitsee ympäristö, tapahtumia ja henkilöitä. Tekstin takana on aina vähintään kaksi siitä vastaavaa agenttia: kertoja, joka näkyy tekstin pintatasolla ja sen takana tekstin kokonaisuudesta vastaava tekijä. Lopullisen tarinamaailman konstruoi yksittäinen lukija. (Ks. Ryan 2001, 15; Nünning 2010, 224, 236; Hatavara 2007, 28-29; 2010, 28; 2014,242 .) Tässä artikkelissa en keskity kumpaankaan toimijaan tarinamaailman taustalla, vaan siihen, mitä tarinamaailma sisältää ja miten se on suhteessa maailmaan, johon oletetut tekijät ja lukijat sijoittuvat. Artikkelin maailmakäsitys on siis lähtökohtaisesti kerroksellinen. (Esim. Ahola 2021b.) Myös sen aineisto on intertekstuaalisesti varsin kerrostunutta kulttuuria: Kalevala-muunnelmat kantavat mukanaan Kalevalan osia, jotka taas sisältävät osia kansanrunoudesta, jota esimerkiksi Lotte Tarkka (2005) on lähestynyt tutkimuksessaan lähtökohtaisesti kerrostuneena, hybridisenä ja moniäänisenä ilmiönä. Tämän artikkelin tutkimuskohteena ovat ensisijaisesti yksittäisten fiktiivisten teosten, kolmen Kalevala-muunnelmaromaanin, tekstuaaliset tarinamaailmat. Vaikka teen jossain määrin päätelmiä niiden ulkopuolisesta kontekstista, valittu teoreettinen lähestymistapa rajoittaa tekstinulkoisten seikkojen käsittelyä.

Kaunokirjallisen maailmakokonaisuuden mallintamiseen on olemassa useita teoreettisia vaihtoehtoja. Yksi tapa on Marie-Laure Ryanin $(1991,51)$ esittämä pienimmän poikkeaman periaate, jonka mukaan fiktiivinen maailma rakennetaan aina todellisen maailman pohjalta ja eroaa siitä vain, kun teksti eroavaisuuteen selvästi viittaa. Käytännössä lukija siis täyttää tekstin jättämät aukot ensisijaisesti tiedolla omasta maailmastaan. Myös fiktiivisen maailmanrakentamisen teoretisoinneissa esiintyy ajatus, että lukija käyttää uusien maailmojen rakentamiseen oman maailmansa aineksia, mukaan lukien omat kokemuksensa ja intertekstuaalisuus. (Nünning 2010, 216-219.) Kalevala-muunnelmien tapauksessa maailmanrakentamisen aineksena toimii tekstin lisäksi lukijalle tuttu nykymaailma, josta on mahdollista ammentaa myös tietoa Kalevalasta ja joka sisältää Kalevalan teoksena. Historiallisessa romaanissa fiktiivisen tarinamaailman rakentamisen onnistumisen edellytyksenä on, että teoksen pohjatietonaan käyttämä historiallinen tieto on lukijan kanssa yhteistä, ja Mari Hatavaran $(2012,89)$ mukaan sen myötä lukija voi rakentaa maailmaa oman tietonsa pohjalta pidemmälle, kuin pelkästään kertojan tarjoaman tiedon pohjalta olisi mahdollista. Tällainen maailmanrakentamisen prosessi on pienimmän poikkeaman periaatteen ytimessä. Myös spekulatiivisessa fiktiossa, joka sisältää fantasia- ja science fiction -kirjallisuuden (ks. esim. Polvinen 2018, 67), pienimmän poikkeaman periaate toimii, mutta maailman aineksista korvautuu tekstin omilla aineksilla suurempi osa muihin kirjallisuuden lajeihin verrattuna (McHale 2018, 327). Sekä historiallisella että fantastisella romaanilla on suhde todelliseen maailmaan. Lukija joutuu näkemään sitä enemmän vaivaa maailman rakentamisessa, mitä enemmän se eroaa hänen omasta maailmastaan (Ryan 2015, 12-13). Kummassakin tapauksessa suhde toimii silti pienimmän poikkeaman periaatteella, joka nousee mahdollisten maailmojen teoriasta (Ryan 1991; 2001). ${ }^{2}$ Keskeistä on käsitys siitä, että jokaisella tekstillä on oma tarinamaailmansa, vaikka siinä olisikin aineksia muista maailmoista. Jokainen fiktiivinen teksti rakentaa oman maailmansa, joka on omanlaisessaan suhteessa niin todelliseen maailmaan kuin mahdollisiin muihin lähdemaailmoihin, kuten Kalevala-muunnelmat Kalevalan maailmaan.

2 Mahdollisten maailmojen teorian mukaan fiktiivinen teksti muodostaa oman maailmansa, joka sisältää lukijan ja tekijän maailman kanssa yhteisiä aineksia enemmän tai vähemmän, mutta on siitä kuitenkin aina erillinen. Tämä maailma korvaa lukijan kokemuksessa tämän oman maailman lukutapahtuman ajaksi (Ryan 2001, 101-102). Mahdollisten maailmojen malli on yksi tapa ratkaista narratologisessa kirjallisuudentutkimuksessa välttämätön kysymys todellisuuden ja fiktion suhteesta. 
Tarkoitan Kalevalan maailmalla rajatusti nimenomaan kansalliseepoksen tekstin tuottamaa tarinamaailmaa, vaikka useissa Kalevala-muunnelmissa onkin vaikutelmia myös muusta kansanrunousaineistosta, kuten vapaasti saatavilla olevista Suomen Kansan Vanhat Runot -materiaaleista ja Vanhasta Kalevalasta (1835). Kalevala-muunnelmilla on yhtymäkohtia myös virolaiseen aineistoon, sillä vajaata puolta Kalevalan aineksista on tavattu myös virolaisessa kansanperinteessä (Siikala 2012, 15). Monet muunnelmien tavat muokata eepoksen tapahtumia olisivat luultavasti löydettävissä näistä eriävien toisintojen lähteistä. Tällainen vertailu ei kuitenkaan ole tarkoituksenmukaista tämän tutkimuksen kontekstissa, koska Kalevala-muunnelmien potentiaalisten lukijoiden ei voi olettaa tuntevan syvällisesti kaikkia näitä lähteitä. Kulttuurista muistia tutkinut Ann Rigney (2004, 383-384) on kiinnittänyt huomiota siihen, kuinka arvostettu teksti voi painua syvälle kulttuuriseen muistiin ja kuljettaa merkityksiään erilaisiin konteksteihin. Vuoden 1849 Kalevala on kansalliseeposstatuksensa vuoksi versioista tunnetuin ja vaikuttanut eniten ympäröivään kulttuuriin. Siksi sitä on luontevaa pitää versiona, johon Kalevala-muunnelmatkin ensisijaisesti viittaavat ja jonka muunnelmien potentiaalisten lukijoiden voi olettaa tuntevan.

Kaikkia Kalevala-muunnelmia yhdistää se, että ne luovat yhteyden Kalevalaan ja aktivoivat sen koko merkityspotentiaalin mukaan tulkintaan (vrt. Tammi 1991, 69). Intertekstuaalisten viittausten on toisaalta nähty vahvistavan fiktion tuottaman maailman uskottavuutta ja todellisuuden illuusiota, toisaalta päinvastoin toimivan maailmaa horjuttavana ja hajottavana elementtinä, joka vieraannuttaa lukijan tekstin maailmasta. (ks. esim. Allen 2011, 80,94 .) Strukturalistista narratologiaa edustava Gerard Genette $(1982,18-19)$ näkee, että teksteille on löydettävissä vakaa merkitys: lukija pyrkii aina palauttamaan tekstin tuntemiinsa rakennejärjestelmiin ja ymmärtämään sen rajattuna kokonaisuutena. Genetteläisittäin intertekstuaalisuus ei ole loputtomiin suuntiin laajeneva viittausten ketju vaan tekstin kokonaisuuteen merkityksiä tuottava väline. Kuten fantasiatutkija Brian Attebery $(2014,2-3)$ on todennut eräästä yleisestä intertekstuaalisesta strategiasta, myyttien käyttämisestä fantasian rakennusaineena: kiinnostavaa ei ole niinkään se, mitä aineksia tekstiin on lainattu, vaan se, mitä merkityksiä niiden avulla on saatu aikaan. Tällaista tarkastelua on aiemmin kohdistettu kalevalaisten elementtien käyttöön ja yhteiskunnallisiin merkityksiin niin historiassa (ks. esim. Fewster 2006) kuin nykypäivänä (Gottelier 2020; Mäkelä 2021), mutta ilmiötä ei ole juuri tarkasteltu kirjallisuustieteellisesti nimenomaan Kalevala-muunnelmissa.

Kysymys intertekstuaalisuuden ymmärtämisestä koossapitävänä tai hajottavana on olennainen, sillä myös Kalevala-muunnelmissa tulkintaa voi viedä kumpaankin suuntaan, kuten Johanna Sinisalon Sankarit-teoksen analyysini tuonnempana osoittaa. Käsitystä intertekstuaalisuudesta tarinamaailman uskottavuutta horjuttavana elementtinä tapaa esimerkiksi metafiktiivisyyden eli fiktion itsensä tiedostavuuden käsittelyn yhteydessä. Ryan (2008, 391392) ajattelee metafiktiivisen intertekstuaalisuuden olevan ominaisuus, joka haittaa lukijan eläytymistä tarinamaailmaan, siis tarinamaailman koherenssia ja uskottavuutta. Samoin on arvioitu historiografista metafiktiota, eli sellaista metafiktiivisyyttä, jossa teos on tietoinen sekä omasta olemuksestaan fiktiona että historian luonteesta kirjoitettuna ja kummankin keinotekoisuudesta (Hutcheon 2002, 68-69; Nünning 2005, 216). Näitä ajatuksia on myös kyseenalaistettu sekä historiallisen että fantastisen kirjallisuuden tutkimuksessa. Hatavaran $(2012,96)$ mukaan asetelma, jossa lukijan tietämys historiasta rinnastuu kaunokirjallisen teoksen esittämään vaihtoehtoiseen versioon samasta asiasta, ohjaa lukijan uudelleenarvioimaan omaa tietämystään. Lopputuloksena on prosessi, jossa lukija rakentaa tarinamaailman käyttäen paitsi teoksen antamaa tietoa myös omaa tietoaan tunnetusta historiasta. 
Spekulatiivisen fiktion tutkimuksessa on kiistetty, että maailman keinotekoisuuden tunnistaminen haittaisi maailman uskottavuutta. Esimerkiksi Hanna-Riikka Roine $(2016,104-105)$ on päinvastoin argumentoinut, että maailman ymmärtäminen yhtä aikaa sekä mahdollisena että keinotekoisena on spekulatiiviselle fiktiolle ominainen lukutapa. Olennainen osa fiktion lukukokemusta on, että lukija ymmärtää sitoutuvansa paitsi mahdollisiin henkilöhahmoihin ja tapahtumiin myös taideteosartefaktiin (Polvinen 2012, 108). Tämä tekstin konstruktioluonteen tiedostaminen mahdollistaa sen, että lukija prosessoi samanaikaisesti sekä fiktiivistä maalimaa että omaa maailmaansa osana lukukokemusta. Historiallisessa romaanissa seurauksena on, että kertojan poikkeavalla tavalla esittämät historialliset tapahtumat korostuvat, kun lukija joutuu tarinamaailman ymmärtämiseksi prosessoimaan omaa teoksen ulkopuolista tietoaan niistä (Hatavara 2012, 84, 89). Kalevala-muunnelmat toimivat samankaltaisesti riippumatta siitä, ovatko ne historiallisia vai fantastisia.

Historiallisen tiedon uudelleenaktivointi ja prosessointi liittyy kulttuuriseen muistiin, joka koostuu toistuvista kulttuurisista materiaaleista, joiden uudelleen käyttäminen vahvistaa ja välittää tietynlaista ymmärrystä yhteiskunnasta ja sen menneisyydestä (Rigney 2004, 365-366; Kaljundi, Laanes ja Pikkanen 2015, 10). Kuten olen aiemmin (Ahola 2018; Ahola 2021a) osoittanut, muunnelmat hyödyntävät lukijan tietämystä Kalevalasta ja sen pohjalta tarinamaailmaan kohdistuvia odotuksia eri tavoin. Samalla ne aktivoivat Kalevalaan liittyvää kulttuurista muistia ja muokkaavat sitä. Nyt kohdistan tarkasteluni siihen, kuinka Kalevala-muunnelmat sysäävät lukijansa prosessoimaan tietämystään Kalevalan taustoista kiinnittämällä huomion eepoksen rakentumiseen kansanrunouden osasista koottuna taideteoksena ja esittämällä eepokselle vaihtoehtoisia syntytapoja. Ensin tarkastelen strategiaa selittää Kalevalan synty sijoittamalla kansanrunous fantasiamaailmaan teoksen Roger Repo ja tuonen väki avulla. Toisena strategiana tarkastelen Kalevalan taustalla olevan kansanrunouden pelkistämistä historiallisiksi tapahtumiksi romaanissa Kalevanpoikien kronikka. Kolmantena tarkastelen romaania Sankarit, joka vastaa kysymykseen, millainen Kalevala olisi voinut olla, jos se olisi tapahtunut nykypäivänä, ja kiinnittää samalla huomion Kalevalan syntyyn rakenteellisin keinoin. Lopuksi pohdin näitä erilaisia tapoja suhteessa toisiinsa ja osoitan, että ne kaikki konkretisoivat omalla tavallaan Kalevalan syntyprosessin lukijalle helposti lähestyttävään muotoon.

\section{Fantasiamaailma Kalevalan takana}

Roger Repo ja tuonen väki on fantasiaa ja rikoskirjallisuutta yhdistelevä teos, jonka tarinamaailmassa on rinnakkain kaksi erilaista maailmaa. Tapahtumat käynnistyvät nykymaailman kaltaisesta maailmasta, josta päähenkilö, yksityisetsivä Roger Repo siirtyy ukkosmyrskyn ja loitsun myötä toiseen maailmaan, jolla pian paljastuu yhtäläisyyksiä Kalevalan maailman kanssa.

- No missä sinun vanhempasi ovat, kysyin minä.

- He ovat poissa. Isä lähti jo aiemmin, äidistä on vasta vähän aikaa. Isän tappoi nuori hurja kauan sitten, emo väheni vanhuuttaan. Sitten tulivat tädit Pohjolan taloon. Minut ne ajoivat pois kuin koiran, lisäsi tyttö lauseensa loppuun ja hänen silmänsä välähtivät vihasta.

- Ei kai ne tädit nyt ihan niinkään voi tehdä. Eivät ainakaan silloin, jos sinä et ole vielä edes täysi-ikäinen. Ja kyllähän nyt perintökaarenkin mukaan lesken kuoltua omaisuus kuuluu rintaperilliselle, siis lapselle. (Roger Repo ja tuonen väki, jatkossa RR, 28.) 
Tämä keskustelu käynnistää romaanin varsinaisen juonen. Roger Repo haastattelee etsivätoimistoonsa Tampereelle saapunutta Kerttua, joka kertoo olevansa Pohjolan tytär ja tarvitsevansa apua saadakseen talon takaisin sen vallanneilta tädeiltään. Kerttu on kotoisin Alisesta maailmasta, ei ollenkaan Revon todellisuudesta, mitä Repo ei vielä tässä vaiheessa ymmärrä. Kertun tarina yhdistyy Kalevalan tapahtumiin: "nuori hurja" Lemminkäinen tappaa Pohjolan isännän Kalevalan 27. runossa, ja Louhi jää yksin hallitsemaan Pohjolaa. Louhen vanheneminen ja kuolema sekä tädit eivät kuulu Kalevalan tarinaan - Roger Revon tarinamaailmassa Kalevalan tarina siis jatkuu. Repo ei tunnista Kertun tarinan yhteyttä Kalevalaan, vaan suhtautuu siihen oman maailmansa lakien näkökulmasta, kuten puhumalla perintökaaresta. Tampere ja perintökaari ovat oletettavasti tuttuja myös lukijan todellisuudessa, mutta henkilöhahmo Repoon nähden lukija on jo askeleen edellä, sillä lukija oletettavasti tunnistaa viittaukset Kalevalaan ja osaa odottaa, että niillä on tarinamaailman henkilöhahmon kannalta merkitystä.

Lukijan ja Revon epätahtinen tapahtumien sisäistäminen on osittain seurausta siitä, että romaanissa on kaksi kertojaa: minäkertoja ja kolmannen persoonan kertoja. Kertojilla on eri verran tietoa tarinamaailmasta. Ensimmäinen luku, joka on kolmannen persoonan kertojan diskurssia, päättyy siihen, että nainen laulaa toisen makuhuoneen lattian läpi suohon $(R R, 8)$. Tämä tapaus on paitsi teoksen ensimmäinen yliluonnollinen tapahtuma myös ensimmäinen selvä intertekstuaalinen viittaus, joka osoittaa teoksen Kalevala-muunnelmaksi ja siten aktivoi Kalevalan mukaan tulkintaan. Ulkopuolinen kertoja kertoo yliluonnollisesta tapahtumasta heti, ja osoittaa kaikkitietävyytensä myöhemmissä luvuissa $(7,11,15)$ antamalla sellaista tietoa, jota minäkertojalla ei ole. Seitsemännessä luvussa ulkopuolinen kertoja taustoittaa tähän asti tapahtunutta ja kertoo lisää siitä, miksi Pohjolan tytär Kerttu lähetti Roger Revon matkaan. Luvussa 11 ulkopuolinen kertoja kuvaa paikkaa ja inmistä, jonka luokse minäkertoja on vasta matkalla. Ulkopuolinen kertoja tietää Kalevala-aineksista ja yliluonnollisesta alusta asti, mutta minäkertoja Repo hyväksyy yliluonnollisen vasta vähitellen. Lukijalle ulkopuolinen kertoja on jo paljastanut yliluonnollisen, kun minäkertoja alkaa vasta epäröidä. Revon epäröintivaihe on lyhyt ja suoraviivainen. Hän herää ukkosmyrskyn jälkeen puhuvan ketun kanssa, ja kuulee tältä joutuneensa Kalevalan maailmaan, jossa hänen pitää matkustaa Pohjolaan $(R R, 37)$. Vielä seuraavana aamuna herätessään Roger Repo toivoo, että kaikki olisi unta $(R R, 43)$, mutta tämän jälkeen hän ei juuri pohdiskele maailman todellisuutta vaan hyväksyy tilanteen, eikä inmettele eteen tulevia yliluonnollisuuksia.

Tarinamaailman menneisyyteen sijoittuu Kalevalan henkilöhahmoja. Roger Repo kohtaa matkallaan Tuonelan jokea alaspäin esimerkiksi ohikulkijoita jousella ammuskelevan Joukan $(R R, 45,47)$, joka vertautuu Kalevalan Joukahaiseen: eepoksen kuudennessa runossa Joukahainen suistaa jousella ampumalla veteen Väinämöisen, joka on matkalla Pohjolaan. Samoin Roger Repo kohtaa kultaneitoja, jotka paljastuvat kopioiksi alkuperäisestä kultaneidosta $(R R, 48,58)$, jonka Ilmari takoi vaimonsa menetettyään. Kalevalassa Ilmarinen takoo kultaneidon samanlaisessa tilanteessa 37. runossa. Roger Revon Kalevala-maailma on rappioitunut ja väkivaltainen. Kalevala-maailman asukas Tapio kuvailee Joukaa sanoilla "vähämielinen", "hölmöläinen" ja "merkityksetön" (RR, 47). Kultaneidot taas kuuluvat MC Kantele -jengiä vastaan sotivalle MC Rauta -jengille, jonka toimintaa Roger Revon seuraavaksi kohtaama henkilöhahmo kuvaa: "Siellä nuo synkät rosvot viettävät mahdottomia juominkejaan ja sekoilevat kultaneitojensa kanssa monilla eri tavoilla" $(R R, 59)$. Kalevalainen aines näyttäytyy luotaantyöntävänä ja irvokkaana. Toisaalta kumpikin tapaus noudattelee Kalevalan käsitystä samasta aiheesta: Joukahaisesta ei enää kuulla tarinassa sen jälkeen, kun hänen äitinsä 
on sättinyt tämän Väinämöisen ampumisesta kuudennessa runossa ja kultaneidon tarina 37. runossa kääntyy opetukseksi, ettei kullalla voi korvata puuttuvaa puolisoa.

Sekä jousella ampujan että kultaneitojen tapauksessa Roger Repo ensin kohtaa Kalevalasta tutun ilmiön tyynesti, mutta kyselee siitä seuraavilta kohtaamiltaan ihmisiltä. Minäkertoja ei kiinnitä huomiota yhteyteen Kalevalan kanssa, mutta eepoksen tunteva lukija tunnistaa sen. Merja Leppälahti $(2015,44)$ on kiinnittänyt huomiota siihen, että Roger Revossa on metafiktion piirteitä. Hän liittää vaikutelman siihen, että teos viittaa itsensä ulkopuolelle, mutta ei avaa ilmiötä tarkemmin. Jatkan hänen ajatustaan ja väitän, että ilmiön ydin on Kalevalan tuominen mukaan fiktiiviseen maailmaan ja selittäminen toisin. Yliluonnollisen hyväksymisen mukana seuraa myös tarinamaailman Kalevalaan liittyvien olettamusten hyväksyminen. Kun teoksen tarinamaailman ulkopuolisessa todellisuudessa sijaitseva teos Kalevala sijoitetaan fiktiivisen tarinamaailman sisälle ja selitetään se syntyneeksi fiktiivisen tarinamaailman sisällä sijaitsevan fantasiamaailman aineksista, tapahtuu eräänlainen kehysten rikkominen. Se on metafiktioiden keino tehdä lukija tietoiseksi siitä, että romaani ei kuvaa lukijan omaa todellisuutta (Hallila 2006, 92-93).

Kato kysymyshän on siitä, että kuten Kalevalasi lukeneena tiedät, perustuu tää meidän homma loitsuille ja lauluille. Sä voit hallita esimerkiksi luonnonvoimia tai parantaa sairauksia jos tunnet niiden ilmiöiden tai sairauksien syntysanat. Elias Lönnrot keräs näitä loitsuja ja manauksia kirjaansa yhteensä lähes kuuskymmentä kappaletta. Sieltä ne voi lukea kuka tahansa yläkerran jurpo. Senkun avaa vaan opuksen kannen. On tietty mahdollista, et kaikkien värssyjen teho ei ole paras mahdollinen, sillä Eliashan muokkasi niitä joltain osin omien, niin sanotusti taiteellisten mieltymystensä mukaisiksi. $(R R, 39$.)

Lainaus on tilanteesta, jossa puhuva kettu selittää toiseen maailmaan siirtyneelle Roger Revolle uuden maailman sääntöjä. Ketun kuvauksesta voi päätellä, että tarinamaailmassa Kalevalan maailma - siis tämän teoksen kontekstissa maailma, jota kettu lainauksessa kuvailee - on paikka, josta Kalevala kertoo epätarkan version. Lönnrot taas on maailmojen välillä matkustava henkilöhahmo tämän tarinamaailman menneisyydessä. Maailmojen välillä matkustavat henkilöhahmot ovat tavanomaisia fantasiakirjallisuudessa, mutta asetelma saa kiinnostavia lisämerkityksiä, kun sitä verrataan siihen todellisen maailman tietoon, joka oletetulla lukijalla on, eli että todellisuudessa Lönnrot teki Kalevalan taustatyönä 11 runonkeruumatkaa, joista suurimman osan Karjalaan. ${ }^{3}$ Niillä hän haastatteli yksittäisiä runonlaulajia, ja loi eepoksen yhdistelemällä myöhemmin eri laulajien yksittäisiä säkeitä tai säeryppäitä ja lisäsi tarvittaessa itse sepittämiään säkeitä sideainekseksi, jotta sai aikaan haluamansa teoskokonaisuuden. Kun tätä tietoa ja romaania luetaan rinnakkain, näyttäytyy romaanin näkemys oman tarinamaailmansa Kalevalan synnystä kiteymänä ja konkretisointina siitä Kalevalan syntyhistoriasta, joka romaanin ulkopuolisessa todellisuudesta tunnetaan. Romaanin tarinamaailmassa pitää käydä fantasiamaailmassa, josta Kalevalan tapahtumat ja henkilöt löytyvät, eikä monta kertaa Karjalassa. Romaanin tarjoama näkemys Kalevalan synnystä näyttäytyy yksinkertaistettuna versiona tavasta, jolla eepos todellisessa maailmassa on luotu. Yksinkertaistus alleviivaa samaa viestiä, joka sisältyy ketun pilkalliseenkin kuvaukseen Lönnrotin työstä. Kettu antaa ymmärtää, että Lönnrotin muokkaustyön takia loitsujen teho on heikentynyt, kun runot eivät enää muokkaajan jäljiltä ole alkuperäisessä asussaan. Tällä tavoin Roger Repo -romaani muistuttaa, että Lönnrotin kokoama Kalevala on vain yksi

3 Yksi Lönnrotin matkoista suuntautui Viroon (ks. esim. Saarelainen 2019, 17), mutta merkittävimät Kalevalan taustoittamiseen liittyvät matkat tehtiin Karjalaan. Esimerkiksi Avoimeen Kalevalaan liittyvässä oppimateriaaliksi suunnatussa yleistajuisessa Matkalla Kalevalaan -verkkoaineistossa mainitaan yksitoista matkaa, mutta ei mainita erikseen kuin Karjalaan suuntautuneita. 
mahdollinen versio, ja yhdistelemällä kansanrunouden aineksia eri tavoilla olisi mahdollista koota hyvin erilaisia kalevaloja. Se taas on tosiseikka, jonka jo Lönnrot itse totesi aikoinaan, mikä edelleen on nostettu Avoin Kalevala -edition etusivulle (9.11.2021) asti ja korostaa nykyaikaista hybridistä käsitystä kansalliseepoksesta.

Roger Revon Kalevala-maailma on myös versio Tuonelasta. Kuten kettu kertoo, sen asukit ovat kuolleita suomalaisia, jotka entisestä elämästään mitään muistamatta elävät osana Ukko Ylijumalan sotaleikkiä Alisessa maailmassa. Kaikilla muilla tavoin paitsi kaulan katkaisemalla tapetut heräävät uudelleen seuraavana aamuna. $(R R, 77-78$.) Roger Revon tarinamaailmassa Kalevala on siis kuvausta tuonpuoleisesta, mitä alleviivaa teoksen lopetus, uutinen kuolleena toimistostaan löytyneestä yksityisetsivästä. Kettu myös ilmoittaa olevansa hänen voimaeläimensä Alisessa maailmassa ( $R R, 36-37)$, mikä yhdistää Revon maailmanvaihdon yhä selvemmin samaanien tuonelamatkoihin (vrt. Siikala 1992, 195, 205). Tätä alleviivaa päähenkilön nimi, Repo, ketun synonyymi. Romaanin tarinamaailmassa sen oma fantasiamaailma on Kalevalan lähde, siinä missä oletetun tekijän ja lukijan maailmassa Lönnrot työsti keräämänsä kansanrunouden aineksia yhdistelemällä taideteoksen nimeltä Kalevala. Tekstin ulkopuolisen maailman kansanperinne korvautuu tarinamaailmassa fiktiivisillä faktoilla: romaanin tarinamaailmassa Lönnrot ei ole saanut Kalevalan pohjana olevia kansanrunouden säkeitä keruumatkoiltaan vaan käynnillä fantasiamaailmassa.

Vaikka tapahtumakulku eroaa lukijan Kalevalan taustaa koskevasta tietämyksestä, sekä teoksen fantasiamaailmassa että nykyajankaltaisessa maailmassa on elementtejä, jotka tekevät niistä lukijan kannalta referentiaalisia. Hatavaran $(2012,85)$ mukaan pienikin viite lukijan tuntemaan todellisuuteen riittää tuomaan sen mukaan tulkintaan. Roger Revon lähtötodellisuudessa sijaitsevat esimerkiksi Tampere ja sen lakikirjoissa perintökaari, jotka lukija tunnistaa omaan todellisuuteensa kuuluvaksi, mutta fantasiamaailman referentiaalisuus rakentuu toisin. Se perustuu intertekstuaalisiin viittauksiin Kalevalasta. Maailmanrakentamisessa referentiaalisuudella on merkitystä: intertekstuaalisilla viittauksilla sekä toisiin kaunokirjallisiin teoksiin että historiaan saadaan aikaan referentiaalisuuden vaikutelma ilman, että tarinamaailmassa sijaitsevista asioista tulisi ontologisesti samoja kuin todellisessa maailmassa (Nünning 2010, 227-228). Referentiaalisuus on tärkeää myös kulttuurisen muistin kannalta. Merkitysyhteys nykyisyyteen on kulttuurisessa muistissa säilymisen kannalta merkittävä tekijä (Rigney 2004, 381). Roger Revon sisäkkäisten maailmojen kokonaisuus ohjaa lukijaa tulkitsemaan teoksen fantasiamaailmaa Kalevalan lähdemaailmana tarinamaailman sisällä, siis ankkuroi teoksen Kalevalan ja nykymaailman kaltaisen tarinamaailman kautta lukijan kokemuspiiriin ja merkitykselliseen nykyisyyteen. Samanaikaisesti, kun lukija hahmottaa omasta todellisuudestaan poikkeavan tarinamaailman, lukijan oma tietämys aiheesta on välttämättä aktiivinen.

Kuten olen aiemmin todennut, samankaltainen eepoksen syntyä tarinamaailman kontekstissa muokkaava asetelma Kalevalan ja oletetun lukijan maailman välillä on kaikissa sellaisissa Kalevala-muunnelmissa, joiden maailmarakenteessa sijaitsee nykymaailman kaltainen maailma ja fantasiamaailma (Ahola 2020,155-156, 162). Kalevalan alkuperän liittäminen fantasiamaailmaan on kuitenkin vain yksi tapa, jolla fiktiiviset faktat korvaavat kansanrunouden Kalevalan lähdeaineistona. Tarkastelen seuraavaksi, kuinka se tapahtuu sijoittamalla Kalevalan tapahtumat historiallisena esitettyyn tarinamaailmaan. 


\section{Historiallisena esitetty maailma}

J. P. Koskisen Kalevanpoikien kronikka (2018) on historialliseen maailmaan sijoittuva seikkailuromaani, jonka päähenkilöitä ovat Kalevalan keskushenkilöihin rinnastuvat tietäjä Väinö, seppä Seppo ja soturi Lemminkäinen, jotka matkustavat kylmästä pohjoisesta Bysanttiin etsimään liittolaisia Ruotsia vastaan. Keskeisin päähenkilö on kertoja Väntti, Lemminkäisen poika, jonka tehtävänä on seurata kalevalaisia sankareita ja raportoida jälkipolville näiden seikkailuista. Sen hän tekee avoimen värikkäällä tavalla, kuten seuraavassa katkelmassa, jossa Väntti keskustelee Lemminkäisen äidin kanssa samalla, kun on johdattamassa äitiä tämän loukkaantuneen pojan avuksi.

\footnotetext{
- Jos poikani kuolee, niin mitä aiot siitä kertoa? hän kysyi, kun olimme leipämme haukanneet.

- En tiedä. Ehkä kerron, kuinka hänet salaa ammuttiin ja lopetan tarinan näin: Niin suistui lieto Lemminkäinen mustaan jokeen, pyörähti pahimpaan pyörteeseen, meni koskessa kolisten, myötävirrassa vilisten, Tuonelan tummille tuville. (Kalevanpoikien kronikka, jatkossa KK, 363-364.)
}

Tilanteessa Lemminkäisen äiti on huolissaan paitsi pojastaan myös siitä, kuinka pojan mahdollinen kuolema jää raportoiduksi jälkipolville. Lemminkäisen tarinan lopetus, jonka kertoja huolestuneen äidin mieliksi keksii, on lähes sanatarkka ${ }^{4}$ sitaatti Kalevalan 14. runosta, jossa kuvataan Lemminkäisen kuolema. Ainoastaan kieliasua on nykyaikaistettu esimerkiksi Kalevalan kielelle tyypillisten vokaalienvälisten h-äänteiden poistamisella. Ainoa potentiaalisesti merkitystä muuttava muutos on Tuonelan tupien luonnehdinta "tummiksi", kun Kalevalan versiossa ilmaus on "tuonne Tuonelan tuville". Ilmauksen "tuonne" poistaminen on mahdollista nähdä nykyaikaistuksena, mutta kalevalaisuuden vaikutelmaa on tuotu toisella tavalla korvaamalla se samaa alkusointua edustavalla sanalla, jonka merkitys sopii kertojahahmon ja hänen kuulijansa tilanteeseen. Pelko Lemminkäisen kuolemasta on läsnä, ja tummat tuvat mainitaan Kantelettaren (1840) 160. runossa "Tuuti lasta Tuonelahan". Kalevala oli heti ilmestymisaikanaan korkeasti arvostettu teos, jonka sankareista haettiin kansakunnan rakennusaineeksi mallia suomalaiselle ylevälle muinaisuudelle, ja sellaisena sitä opetettiin kouluissa pitkään ilmestymisensä jälkeen (Apo 2004, 279; Fewster 2006, 20; Anttonen 2005, 145). Sitaatin avulla luotu yhteys erityisesti ilmestymisaikanaan arvostettuun Kalevalaan vetää saman ylevyyden vaikutelman Väntin kuvaamaan Lemminkäisen kuolemaan, ja korostaa siten äitiä lohduttavaa vaikutelmaa lukijan silmissä.

Kun sitaatti suhteutetaan tarinamaailmaan ja kertojan rooliin sen rakentajana, tulkinnalliset seuraukset ovat mittavat. Väntin kertomus sijoittuu vuoteen $1152(K K, 11)$ Miklagårdiin, joka on historiallinen todellisen maailman paikka, Konstantinopoli, Bysantti tai nykyinen Istanbul, jota viikingit nimittivät Miklagårdiksi. Lukijan maailmassa sijaitsee myös teos Kalevala, josta kertojan sitaatti on peräisin. Kalevanpoikien kronikan tarinamaailmassa kertoja sijoittelee kertomukseensa Kalevalan tapahtumia, henkilöitä ja jopa suoria sitaatteja Kalevalasta ajassa lähes 700 vuotta ennen Kalevalan kokoamista. Asetelma implikoi, että tämän teoksen tarinamaailmassa juuri kertojan kuvaamat tapahtumat ovat alkutapahtumat, joiden pohjalta ovat syntyneet kansanperinteen runot, jotka Lönnrot yli 600 vuotta myöhemmin keräsi ja loi Kalevalan, ja kertoja Väntti näyttäytyy Kalevalan pohjana olevien runojen sepittäjänä. Kalevanpoikien kronikka käyttää itsensä ulkopuolisen maailman aineksia tämän tulkinnan

4 Tuonen mustahan jokehen / Pahimpahan pyörtehesen; / Meni lieto Lemminkäinen, / Meni koskessa kolisten, / Myötä-virrassa vilisten / Tuonne Tuonelan tuville. (Kalevala, 104.) 
mahdollistamiseksi. Jos teoksen maailmaa ja todellisen maailman historiaa verrataan keskenään, voidaan todeta, että tämänkin teoksen tarinamaailmassa fiktiivinen fakta korvaa kansanrunouden Kalevalan lähdeaineistona.

Todellisen maailman tekeminen ensin tunnistettavaksi fiktiivisen maailman sisällä ja sitten sen peukaloiminen toisenlaiseksi on leimallista Hutcheonin $(2002,68)$ määrittelemälle historiografiselle metafiktiolle. Asetelma, jossa lukijan tietämys historiasta rinnastuu kaunokirjallisen teoksen esittämään vaihtoehtoiseen versioon samasta asiasta, ohjaa lukijan uudelleenarvioimaan omaa tietämystään (vrt. Hatavara 2012, 90). Historiallisena esitetyssä Kalevanpoikien kronikassa prosessi ja sen synnyttämä vaikutelma muistuttaa paljon fantastisen Roger Revon vastaavaa. Kummankin romaanin tarinamaailmassa Kalevalan annetaan ymmärtää olevan seurausta tarinamaailman tapahtumista. Erona on, että Roger Revon tapahtumat sijoittuvat Kalevalan tapahtumien jälkeiseen aikaan, kun taas Kalevanpoikien kronikan maailma asemoi itsensä Kalevalaa edeltävään aikaan. Kehysten rikkomisen ilmiö, joka saa lukijan spekuloimaan ja vertaamaan teoksen antamaa versiota Kalevalan synnystä ja oman todellisuutensa tietämystä aiheesta, on kuitenkin molemmissa sama.

Kalevanpoikien kronikka -romaanin Kalevalan taustoihin kohdistama uudelleenarviointi ulottuu laajemmallekin alalle. Siinä missä Roger Revon tarinamaailmassa prosessi pysähtyy oivallukseen, että kansanrunous Kalevalan aineistona on tarinamaailmassa korvattu fantasiamaailmasta peräisin olevalla aineksella, historiallisena esitetty Kalevanpoikien kronikka sysää lukijansa syvempään suhteeseen tarinamaailman kanssa. Hatavara $(2012,96-97)$ esittää, että prosessoidessaan historiallista tarinamaailmaa itse tekstin ja oman maailmansa historiallisen tietämyksensä kautta lukija asettuu niin tiiviiseen suhteeseen tarinamaailman kanssa, että pystyy jopa näkemään itsensä osana tarinamaailman todellisuutta, jossa on yhteisiä elementtejä hänen omasta todellisuudestaan. Tämä on Kalevala-muunnelmienkin tapauksessa mahdollista niin kauan, kunnes muunnelman tarinamaailma osoittautuu liian ristiriitaiseksi lukijan todellisuuden kanssa. Tässä mielessä historiallisena esitetty tarinamaailma vie Kalevalan alkuperällä spekuloinnin pidemmälle kuin fantastinen maailma, joka yliluonnollisten tapahtumiensa vuoksi pakottaa tunnustamaan maailmojen erot nopeammin.

Heidi Henriikka Mäkelä (2021) näkee kalevalaisen aineksen käytössä kahtalaisen vaikutuksen: se toisaalta etäännyttää, toisaalta on tuttua, jolloin lopputuloksena on nykyihmisen kannalta riittävän kaukainen mutta silti kiinnostava tarinamaailma. Silloin, kun soveltamisen kohteena on nimenomaan Kalevala teoksena eikä kalevalamittainen esitys ylipäätään, tilanne on hieman erilainen, koska Kalevala on teoskokonaisuus, toisin kuin kalevalamittaisuus ilmiönä. Mäkelä (mt.) tarkastelee kalevalaisten elementtien käyttöä kulttuurisen muistin näkökulmasta elävöittämässä keskiaikaisia henkilöhahmoja, jolloin kalevalamittainen runous näyttäytyy autenttisuutta tuovana elementtinä tarinamaailmassa. Tämä ilmiö on havaittavissa Kalevanpoikien kronikassa tarinan tasolla, mutta kokonaisuudessa asetelma on toisinpäin. Romaani esittää Kalevalan henkilöhahmot inhimillisinä ja helpommin lähestyttävänä kuin Kalevalassa. Sen mahdollistaa paitsi henkilöhahmojen kuvaaminen korostetun inhimillisinä myyttisen sijaan, myös esitystapa. Eepoksen tyypillisiä piirteitä ovat asiantuntevat kertojat, mytologian ja historian limittyminen, kulttuurinen kattavuus ja laajuus kertomuksena (Honko 1987, 12). Myös romaania määrittää muodon kertovuus, ja se voi käsitellä mitä tahansa aihepiiriä - myös myyttisiä ja historiallisia limittyneenä. Ennen romaanin läpilyömistä eepos oli suomalaisen kulttuurin suosituin kirjallinen laji (Hatavara 2007, 40). Erona on paitsi eepoksen mitallisuus, myös se, että eepokselle ominaista on sijoittua kokonaan 
sulkeutuneeseen ja tarkemmin tavoittamattomaan menneisyyteen, kun taas historiallinen romaani asettuu jatkumoon lukijansa kanssa esittäytymällä tämän kanssa yhteisen maailman menneisyyden kuvauksena (mt., 33). Romaanin suhde lukijan maailmaan on tätä kautta lähtökohtaisesti jatkuvuuteen perustuva, kun taas eepoksen irrallinen.

Romaanin Kalevanpoikien kronikka kertoja on paitsi erehtyväinen ihminen myös omasta kertomisestaan hyvin tietoinen. Kerrontansa kuluessa tämä reflektoi avoimesti omaa kerrontaansa ja selvittää yleisölle taustavaikuttimiaan, joihin ei aina kuulu ensisijaisena pyrkimys totuuteen, vaan tärkeämpää on esimerkiksi yleisön viihdyttäminen. ${ }^{5}$ Se näkyy tavoissa, joilla kertoja arvioi omaa kertomustaan. Kertoja toteaa esimerkiksi: "Ehkä tarina ei ollut edes totta, mistä minä sitä saatoin tietää. Lisäilinhän itsekin tarinoihin uusia käänteitä, jos kuulijat pirtin nurkissa alkoivat haukotella." $(K K, 61)$ Repliikissä kertoja arvioi jonkun toisen kertomaa tarinaa ja toteaa sen mahdollisesti epäluotettavaksi tiedoksi, mutta vertaa siihen omaa kerrontaansa ja tunnustaa samalla muokkaavansa kertomansa sisältöä sen mukaan, mitä kuulijakunta vaikuttaa edellyttävän. Omaa kerrontaansa kommentoiva kertoja on yksi avoimen metafiktion piirteistä (Hutcheon 2014, 22-23). Metafiktiivisessä historiallisessa romaanissa epäluotettava kertoja korostaa historiankirjoituksen yleistä epävarmuutta: avoimesti henkilökohtaista versiota esittävä kertoja etualaistaa sen, että historiasta ylipäätään ei ole olemassa kuin aiemmin kirjoitettuja versioita. (Hietasaari 2015, 303.) Se, että kertoja paljastaa pohdinnallaan oman epäluotettavuutensa tapahtumien toisintajana, on vihje myös lukijalle herkistyä epäilemään kuvaa, jonka kertoja tarinamaailmasta antaa.

Kertojan epäluotettavuutta kiinnostavampaa Kalevanpoikien kronikan kertojan kommentoivassa kerrontaotteessa on sen herättämä maailmojenvälinen spekulaatio, jonka myötä tarkastelun piiri ulottuu yli romaanin kerronnan taustalla olevien tapahtumien ja niiden raportoinnin mahdollisen oikeellisuuden aina Kalevalan taustoihin asti - tarinamaailman sisällä. Se, että Kalevala-muunnelman kertojan kuvaamat tapahtumat ehdottavat itseään kansanrunouden lähdeaineistoksi teoksen omassa tarinamaailmassa, kiinnittää huomion kansanrunouden tiedonmuodostuksen kysymyksiin. Kansanrunouden todelliset syntymekanismit tulevat rinnastetuksi avoimesti epäluotettavan kertojan vertailuun siitä, kuinka tapahtumat oikeasti tapahtuivat ja kuinka hän aikoo niistä raportoida. Tarinamaailman asetelma on voimakkaassa ristiriidassa sen todellisesta maailmasta tunnetun seikan kanssa, että kansanrunouteen kohdistui erityisesti kansallisromanttisina Kalevalan syntyaikoina ja kohdistuu edelleen sekä tieteellistä että taiteellista arvostusta. Kansanrunouden koko kaaren pelkistäminen tavallisiin erehtyviin ihmisiin, joista raportoi yksi yhtä erehtyväinen, synnyttää ironiaa. ${ }^{6}$ Toisaalta kertojan rinnastuminen Lönnrotiin Kalevalan kokoonpanijana muistuttaa, että Kalevalan taustalla oleva kansanrunous on eepoksesta irrallaan olemassa yksittäisten

5 2000-luvun Kalevala-muunnelmaromaanien joukossa on monta teosta, jossa joku henkilöhahmoista esitetään kertomuksesta vastaavaksi. Kyse ei ole vain minäkerronnasta, vaan kertojan rooli suhteessa kertomukseen ja Kalevalaan on aina jollain tavalla kohosteinen, ongelmallinen tai yllättävä. Seija Vilénin romaanissa Pohjan akka (2012) on kaksi henkilöhahmoa, jotka pyrkivät yhdessä saman tarinan kertomiseen, eikä teos anna yksiselitteistä vastausta siihen, kumpi heistä kokonaisuutta hallitsee vai hallitseeko kumpikaan. Juha Ruusuvuoren Lemminkäisen laulussa (1999)kuvataan, kuinka minäkertoja viikinki Ahti Saarelainen tuntee taianomaista vetoa kirjoitukseen ja oppii kirjoittamaan. Timo Parvelan Sammon vartijat -nuortenromaanitrilogian ensimmäisen osan (Tuliterä 2008) lopussa päähenkilöitä auttanut vanhus kuolee ja tekee yhdestä heistä, Annista, kertojan. Toinen osa Tiera (2009) alkaa Annin minäkerronnasta, ja vaikka vielä siirrytäänkin kolmannen persoonan kerrontaan, sen voi tulkita Annin vastuulle.

6 Samanlaista ironiaa ei synny kaikissa Kalevala-muunnelmissa, joissa on henkilökertoja, vaikka asetelma kansanperinteen korvautumisesta fiktiivisillä faktoilla olisi samankaltainen. Ero on tavassa, jolla kertoja tapahtumia ja henkilöitä kuvaa. Esimerkiksi historiallisessa Kalevala-muunnelmaromaanissa Lemminkäisen laulu minäkertoja Lemminkäinen on aivan yhtä erehtyväinen ja inhimillinen kuin Kalevanpoikien kronikan henkilöhahmot, mutta häntä kuvataan ymmärtäen. 
runonlaulajien esityksistä tallennettuina katkelmina, joiden yhdistelmästä teos Kalevala on vain yksi mahdollinen kokonaisuus. Hieman samaan tapaan kuin runonkeruumatkat pelkistyvät käyntiin fantasiamaailmassa Roger Revossa, Kalevanpoikien kronikassa moniääninen runonlauluperinne ja yksittäiset runonlaulajat Kalevalan taustalla pelkistyvät yhteen epäluotettavaan, erehtyväiseen ja inhimilliseen kertojaan.

\section{Nykymaailma ja tekstin kokoonpanon viestit}

Johanna Sinisalon romaani Sankarit sijoittaa Kalevalan tapahtumat nykyaikaan, pääosin 1990-luvun Suomeen. Muunnelma noudattelee eepoksen juonikulkuja tarkasti, mutta etsii henkilöille ja tapahtumille vastineet nykyajasta. Teoksen väinämöishahmo on rocktähti Rex, ilmarishahmo koodari-muusikko lle ja lemminkäishahmo uransa nousut ja laskut elävä urheilusankari Mahti. Sankarit-romaani on asetelmaltaan sikäli erilainen kuin Kalevanpoikien kronikka tai Roger Repo ja tuonen väki, että sen tarinamaailma ei suoraan ehdota itseään Kalevalan lähteeksi, kuten edelliset teokset tekevät toinen historian, toinen fantasian keinoin. Silti Sinisalon romaaninkin rakenteessa on itsensä tiedostavuuden piirteitä ja se ottaa kantaa Kalevalan koostamiseen. Sankareissa nämä piirteet eivät ankkuroidu aiemmin käsittelemieni teosten tavoin Kalevalan selittämiseen tarinamaailmassa tai yksittäiseen kertojahenkilöön vaan näihin nähden korkeammalle tasolle, koko romaanin rakenteeseen ja tekstuaaliseen kokoonpanoon, joissa kalevalaisen tarina-aineksen luonne toistettuna ja muunnettuna korostuu.

Romaanissa käytetään Sinisalolle tyypilliseen tapaan varsinaisen kertojan osuuksien lisäksi niin fiktiivisiä kuin tunnistettavia intertekstuaalisia lainauksia erilaisista tekstilajeista. Nämä lainaukset kuljettavat juonta eteenpäin. Esimerkiksi Kalevalasta tuttu kilpakosintaepisodi on kuvattu fiktiivisellä lehtiartikkelilla ja katkelmalla romaanista. Sankarien varsinainen ulkopuolinen kertoja kuvaa, kuinka Ile Aerosmithin eli teoksen ilmarishahmon sisar Annikki kertoo veljelleen, että Rex on menossa kosimaan Ilelle luvattua naista, Pohjolan Tyttiä (Sankarit, jatkossa S, 194). Luku loppuu tähän, ja ennen seuraavaa lukua tekstiin on sijoitettu kaksi fiktiivistä lainausta. Niistä ensimmäinen on lähteistetty katkelmaksi artikkelista Annikki Hämärisen "Vuosikymmenen kilpakosinta - entiset yhtyetoverit hamuavat samaa kättä. Näin lle Aerosmith valmistautuu voittamaan valittunsa sydämen" "Muoti \& Kauneus 1/1995" (S, 195):

Romanttinen kilpailu saman naisen kädestä ja sydämestä tuntuu olleen viimeisinä vuosina uhanalainen urheilulaji. Ainakaan julkisuuspiireissä tällaisia tarinoita ei ole kovin tiheään nähty. Sitäkin hurmaavampi on rocktähti Rexin ja hänen pitkäaikaisen yhtyetoverinsa lle Aerosmithin keskinäinen kilpailu entisestä kauneuskuningattaresta ja nykyisestä huippututkijasta Tytti Pohjolasta. Koko tarina on kuin satua, kuin mitä henkeäsalpaavimmasta rakkausromaanista. $(S, 196$.

Heti tämän lainauksen jälkeen alkaa seuraava, joka onkin edellisen lainauksen ennakoimalla tavalla "Katkelma rakkausromaanista", jonka on kirjoittanut kirjailijanimi Annie Twilight:

Muutaman hälytysäänen jälkeen puhelimeen vastataan.

"Tässä on lan Drummer."

Toisessa päässä ei kuulu hetkeen kuin helikopterin säksätystä. Sitten kuuluu Reginaldin ääni, joka lanin tyydytykseksi hivenen vavahtaa. "Niin."

"Katso alas tielle. Näet kuparinvärisen avo-Saabin joka ajaa samaan suuntaan kuin sinä lennät", Ian sanoo. "Se olen minä, ja samalla asialla kuin sinä." 


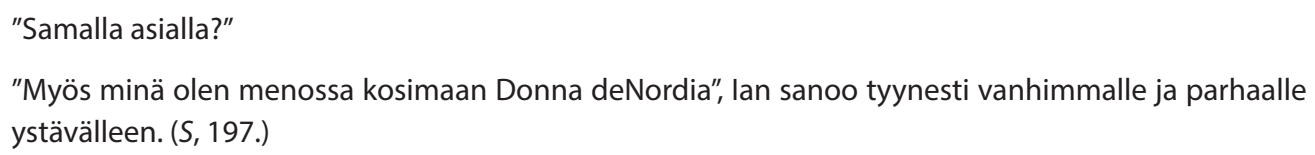

Lainaukset ovat sinänsä tavallisia sisäkkäiskertomuksia eli tarinamaailman sisällä sijaitsevia tekstejä. Niin toimittaja Annikki Hämärinen kuin kirjailijanimi Annie Twilight yhdistyvät Ilen Annikki-siskoon, eikä se, että sisko olisi kirjoittanutkin tekstit, sodi tarinamaailman lainalaisuuksia vastaan. Annikki paljastaa llelle Rexin kosivan Tyttiä luvussa, jonka aikamääreeksi on ilmoitettu tarinamaailman ajassa "vuodenvaihde 1994-1995" $(S, 192)$, lehtiartikkeli on ilmestynyt tammikuussa 1995 ja romaani myöhemmin, vuonna 1996 (S, 197). Samankaltaisia Rexin eri nimillä kirjoittamaksi esitettyjä tekstejä romaanista löytyy myös, ja miksipä ei rocktähti voisi elämästään kirjoittaa vaikka jännitysromaanin muodossa, jollaisena Sammon ryöstö -episodi on kuvattu kirjailijanimi Roi Vesan kirjoittamana $(S, 356)$. Paitsi henkilöhahmojen nimiä muistuttavat taiteilijanimet, katkelmien tarinan juonta eteenpäin kuljettaviksi tunnistamista edesauttaa myös se, että juoni on Kalevalasta tuttu. Aktiivinen Kalevala-suhde ei tee muunnelmista vaikealukuisia, tai, kuten Sankarit-romaania tutkinut Eliisa Pitkäsalo $(2009,200)$ toteaa teoksen henkilöhahmoista, romaanin vieraannuttavat keinot eivät haittaa henkilöhahmojen uskottavuutta. Ryan $(2008,394)$ pitää tällaista tekstin fiktiivisyyttä korostavaa intertekstuaalisuutta lähtökohtaisesti lukukokemusta häiritsevänä. Kalevala-muunnelmissa suhde Kalevalaan ei kuitenkaan vaikuta tarinamaailmaan hajottavasti vaan päinvastoin rakentavasti. Kuten olen aiemmin havainnut, jossain tapauksessa intertekstuaalinen yhteys Kalevalaan jopa kannattelee muuten haastavasti hahmottuvaa tarinamaailmaa (Ahola 2021a, 18). Sankarit-romaanissakin pirstaleisesti rakennetun romaanin kokonaisuuden hahmottamista auttaa lukijan Kalevalan tuntemus.

Toisaalta kuvitteellisten rakkaus- tai rikoskirjallisuuden katkelmien tuominen Kalevala-muunnelman sisälle edustaa pienoiskoossa samaa ilmiötä, jonka olen aiemmin (Ahola 2021 b, 188) havainnut dekkarin käyttämisestä Kalevala-muunnelman muotona: vetävä ja helposti lähestyttävä kirjallisuudenlaji auttaa lukijaa käsittelemään Kalevalan sisältöjä, joihin tutustuminen eeposmuodossa on tottumattomalle lukijalle haastavampaa. Toisaalta lajien moninaisuus itsessään on osa Kalevala-muunnelman Kalevalan taustan kerroksellisuuden kertaamista: kuten Lotte Tarkka (2005, 384-385) toteaa, omana aikanaan suosittujen ja hyvämaineisten runonlaulajien esitykset olivat lajiltaan ja keinovalikoimaltaan hybridisiä, ja tuolloinenkin yleisö ymmärsi intertekstuaalisin keinoin painotetut viestit ja arvosti intertekstuaalisia esityksiä.

Kalevala-muunnelmien tarinamaailman ja Kalevalan maailman välillä on aina yhteys. Yksi tapa tarkastella eri teosten maailmojen välisiä yhtäläisyyksiä on transfiktionaalisuuden käsite, joka kuvaa eri mediasta ja tarinasta toiseen liikkuvia maailmoja. Ryan (2008, 388-392) asettaa transfiktionaalisuudelle neljä ehtoa: siihen liittyy suhde kahden teoksen välillä, kahdella toisiinsa suhteessa olevalla tekstillä on erilliset maailmat, jotka kuitenkin liittyvät toisiinsa, lukijan on tunnistettava alkuperäisen teoksen maailma ja jälkimmäisen teoksen maailman tekstuaalisuus ei etualaistu siten, että se haittaisi maailman uskottavuutta. Kolme ensimmäistä ehtoa täyttyvät Kalevala-muunnelmissa ylipäätään jo määritelmässä, että ne ovat teoksia, jotka toisintavat vähintään maailman, jossa Kalevala olisi voinut tapahtua. Neljäs ehto ei kuitenkaan sovi yhteen muunnelmien tiedostavan Kalevala-suhteen kanssa. Neljännessä ehdossa olennaista on, että lukija pääsee transfiktionaalisen tekstin maailmaan sisälle ikään kuin oikotietä toisen tekstin jo tutun maailman kautta. (mt., 392-393.) Näin kieltämättä 
tapahtuu myös tarkastelluissa Kalevala-muunnelmissa, erityisesti Sankareissa, jossa Kalevalan tuntemus edistää teoksen oman tarinamaailman tapahtumien hahmottumista. Kalevalan ja muunnelman suhde on kuitenkin aktiivisempi kuin Ryanin transfiktionaalisuuden ajatus antaa myöten.

Pitkäsalo $(2009,53)$ on todennut Sankarit-romaanista, että Kalevalan mytologisten hahmojen esittäminen nykyajan ihmisinä arkipäiväistää niitä. Saman totesin aiemmin Kalevanpoikien kronikan inhimillisistä hahmoista ja epäluotettavasta kertojasta, ja sama vaikutelma on mahdollista nähdä siinä, että Roger Revon tarinamaailmassa Kalevalan henkilöhahmot ovat Tuonelassa muiden kuolleiden kuolevaisten joukossa. Pohjimmiltaan kaikki kansanrunouden fiktiivisillä faktoilla korvaavat Kalevala-muunnelmat raivaavat Kalevalan tapahtumille tarinamaailman todellisuudessa paikan, joka on nykyhetkelle läheisempi ja helpommin saavutettava kuin tarinamaailman ulkopuolisessa todellisuudessa. Toisaalta tämä myyttisen maailman ja yleisön maailman yhteensovittaminen on historiallisenkin kansanrunouden ilmiö, kuten Lotte Tarkan $(2005,135)$ havaitsema kahdentuvan näyttämön runous osoittaa. Hän tarkoittaa sillä tilanteita, jossa runonlaulaja esittää loitsun mytologisen taustan ja sitten käyttää itse samaa loitsua - siis sulauttaa mytologisen maailman omaan maailmaansa, kuten Kalevala-muunnelmissakin Kalevalan maailma tuodaan oletetun lukijan maailman kanssa yhteyteen. Kalevala-muunnelmien perinnettä siirtävä maailmojen yhteenkietomisen tapa on siis tavallaan kertaantunutta perinnettä sekin.

Sankarit-romaani on eepoksen versioiva uudelleenkirjoitus nykyaikaan, ja romaanin omat sisäkkäiskertomuslainaukset kertaavat tämän prosessiin versioimalla romaanin tarinaa jälleen uusissa tekstilajeissa, kuten lehtiartikkeleina, jännitys- tai rakkausromaanina, kirjeenä, laululyriikkana... Romaanin katkelmien suhteuttaminen Kalevalaan tuo niihin myös metafiktiivistä ironiaa. Pitkäsalo $(2009,73)$ on tulkinnut Sankarien sisäkkäiskertomuksia eri nimillä kirjoittavia henkilöhahmoja merkkinä Kalevalan symbolisesta hajoamisesta takaisin kansanrunouden fragmenteiksi - niin kuin Lönnrot joutui yhdistelemään eri hahmoja saadakseen aikaan Kalevalan hahmot, Sankareissa moneksi eri identiteetiksi jakautuvat samaiset koostetut hahmot purkautuvat taas. Pitkäsalon ajatus muistuttaa historiografisen metafiktion perusajatusta, jossa korostuu yhtenäisenä faktatietona esitetyn historian hajoaminen takaisin nykyhetken elämisen kaltaisiksi irrallisiksi hetkiksi (vrt. Hutcheon 2002, 61, 68). Esittämällä, että samoja tapahtumia voi versioida yhä uudelleen uusiksi teoksiksi uusissa tekstilajeissa jopa saman teoksen sisällä, romaani riisuu ainutlaatuisuuden Kalevalan tapahtumilta. Toisaalta romaani kumoaa omalla kertovalla rakenteellaan tämän tarinamaailmastaan hahmottuvan Kalevalan ainutlaatuisuutta aliarvioivan vaikutelman: Romaanin Kalevalan syntyä samoja tarina-aineksia muuntelemalla ja kierrättämällä symboloiva rakenne kiinnittää huomion nimenomaan sekä Kalevalan että romaanin itsensä intertekstuaaliseen konstruktioluonteeseen ja kokoonpanoon, joka on varsin tarkoituksellinen, ei sattumanvarainen. Romaani ei omassa tarinamaailmassaan tarjoudu samalla tavalla Kalevalan lähteeksi kuin muut käsitellyt teokset, mutta silti sekin kertomuksensa rakenteella alleviivaa eepoksen ominaisuuksia ja syntyhistoriaa.

Kalevalan fragmenteista rakennettuuden konkretisoiminen muunnelmassa kiinnittää huomion Lönnrotin Kalevalan kokoamisen prosessiin ja avaa lukijalle uusia tapoja ymmärtää sitä. Tämän huomion myötä Sankarit liittyy Kalevalan todellisen synnyn piirteitä versioivaan mutta samalla kiteyttävään ja korostavaan ketjuun. Olen jo osoittanut, että ketjuun kuuluvat myös Roger Repo ja tuonen väki, jossa runonkeruumatkat tiivistyvät fantastiseen maailmojen 
väliseen matkaamiseen, ja Kalevanpoikien kronikka, jossa runonlaulajat pelkistyvät epäluotettavaan kertojaan. Nämä kaikki ovat yhteisenä ilmiönä sukua spekulatiivisen fiktion tavalle muuttaa kirjallisuuden omia rakenneaineksia konkreettisiksi. Tällainen kirjallisuus leikittelee perinteisillä kuvakielisillä ilmauksilla kuten metaforilla ja tekee niistä konkreettisia omissa tarinamaailmoissaan. Konkretisoinnin kohteena eivät ole vain kielikuvat, vaan myös kertomuksen rakenteet ja kertomusteoreettiset hahmotelmat itsessään. (McHale 2018, 317-319; Polvinen 2018 , 68.) Brian McHale $(2018,327)$ esimerkiksi esittää, että scifikirjallisuus konkretisoi teoriaa maailmanrakentamisesta paitsi esittelemällä konkreettisesti useita maailmoja myös rinnastamalla tarinamaailman sisällä tapahtuvan uuden maailman rakentamisen siihen maailmanrakentamisen prosessiin, jota lukija lukiessaan käy läpi. Kalevala-muunnelmien tapa konkretisoida ja pelkistää omassa tarinamaailmassaan osasia Kalevalan todellisesta syntyprosessista ja toisaalta niiden koostuminen osittain Kalevalan tarina-aineksista ja osittain omaperäisistä tarina-aineksista konkretisoi tätä taustaa vasten tarkasteltuna paitsi McHalen esittämällä tavalla maailmanrakentamisen prosessia myös monimutkaista teoreettista ilmiötä intertekstuaalisuus.

Samanaikaisesti Kalevalan tapahtumien kertaaminen tavalla millä hyvänsä osallistuu niiden säilyttämiseen ja eteenpäin kuljettamiseen - kansanperinteen tehtävän jatkamiseen. Vetävä kertomusmuoto ja historiallisen asian esittäminen jollain tavalla merkityksellisenä nykypäivän näkökulmasta ovat ominaisuuksia, jotka edesauttavat yksittäisen kulttuurintuotteen ilmentämien asioiden jäämistä osaksi kulttuurista muistia (Rigney 2004, 379-381). Siihen liittyy Kalevalan synnyn selittäminen uudelleen Kalevala-muunnelmien tarinamaailmoissa siten, että se tulee lähemmäs lukijan maailmaa. Kalevalan tapahtumia ja henkilöitä ei Kalevala-muunnelmissa esitetä välttämättä ylevinä, vaan päinvastoin Roger Repo -romaanin Kalevala-maailma näyttäytyy luotaantyöntävänä ja irvokkaana, Kalevanpoikien kronikan sankarit ovat tavallisia erehtyväisiä ja inhimillisiä kuolevaisia ja Sankarit-romaani ironisoi kuvaamiansa tapahtumakulkuja ja hahmoja sekä koko Kalevalan syntyprosessia.

Useissa Kalevala-muunnelmissa Kalevala-aineksen esittäminen radikaalistikin toisin ja tuominen uusiin yhteyksiin on keskeistä. Silti, kuten Mäkelä (2021) havaitsee, nykypäivänäkään kalevalaisuuden taustalta eivät ole karisseet pois historialliset nationalistisuuteen kiinnittyvät tavat ymmärtää Kalevala myyttisenä mutta kuitenkin suomalaisen kansan menneisyytenä. IImiö on intertekstuaalisuuden kannalta varsin ymmärrettävä: tekstin ja sen pohjalta syntyneen uuden tekstin välille syntyy aina kaksisuuntainen suhde, jonka myötä vanha teksti vaikuttaa uuteen siinä missä uusi voi kommentoida vanhaa (Genette 1997, 5). Vaikka Kalevala-muunnelman tarkoituksena olisi muokata kulttuurista muistia ja saada lukija näkemään Kalevala jollain tavalla toisin - ja vaikka se onnistuisikin - Kalevalan asema suomalaisessa kulttuurissa on niin syvään iskostunut, että muutokset kulttuurisessa muistissa eivät ole radikaaleja ja alkuperäiset merkitykset tulevat samalla kerratuksi ja vahvistetuksi, oli se sitten teoksen alkuperäinen tarkoitus tai ei.? ylevien sotakuvausten kanssa asettuminen niihin naurettavassa valossa viittaamalla on omiaan muuttamaan suhtautumista kyseisiin kuvauksiin, mutta toisaalta samanaikaisesti toisintaa niiden perinteisiä merkityksiä. 


\section{Lopuksi}

Kalevala-muunnelmat eivät muuntele pelkästään Kalevalaa vaan myös sen syntykontekstia. Samalla tarinamaailman versio Kalevalan taustoista vertautuu siihen tietoon, jota lukijalla on oman maailmansa Kalevalasta. Tämä vertailu ja käynnistyvä spekulaatio siitä, millaisia seurauksia lukijan omalle maailmalle olisi, jos romaanien tarjoama versio Kalevalan taustoista olisikin totta toisessakin maailmassa, on Kalevala-muunnelmissa olennaista. Se kietoo Kalevalan yhteen todellisen maailman kanssa ja tekee lukijan suhteesta aktiivisen - ei pelkästään käsillä olevaan romaaniin vaan itse Kalevalaan ja lukijalla olevaan tietoon sen syntykontekstista. Olen tässä artikkelissa tarkastellut kolmea tarinamaailmaltaan erityyppistä Kalevala-muunnelmaa ja todentanut, että ne kaikki kuvaavat muunnellen Kalevalan syntyprosessia lukijan maailman lähtökohdista - käytännössä korvaamalla kansanrunouden fiktiivisillä faktoilla tarinamaailmassaan. Romaanissa Roger Repo ja tuonen väki Lönnrotin runonkeruumatkat konkretisoituvat käynniksi fantasiamaailmassa, Kalevanpoikien kronikassa eepoksen taustalla oleva kansanrunouden kerääminen, valikointi ja koostaminen yhtenäiseksi Kalevalaksi alkuperäistä aineistoa muunnellen vertautuu epäluotettavan kertojan kronikointinsa pohdiskeluun ja Sankareissa tarina-ainesten kierrättäminen eri tekstilajeissa romaanin sisällä muistuttaa muuntelevan eteenpäin kuljettamisen prosessista, joka ulottuu runonlaulun suusta suuhun periytyvyydestä Kalevalan kautta eri vuosikymmenten Kalevala-muunnelmiin, joita ilmestyy yhä jatkuvasti lisää.

Kun Kalevalaa käytetään nykyromaanin pohjatekstinä, seurauksena on uuden ja vanhan tekstin välinen suhde, joka tuottaa merkityksiä kumpaankin suuntaan. Kalevalasta lainatut ainekset kantavat mukanaan merkityksiä Kalevalan kontekstistaan ja tuovat ne mukaan kohtauksiin, joissa niitä käytetään uusissa romaaneissa. Muuttamalla kansanrunouden joksikin muuksi Kalevala-muunnelmat kiinnittävät huomion juuri kansanrunouteen, sen keruuseen ja prosessointiin eepokseksi. Jokainen Kalevala-muunnelma sekä uudelleentulkitsee Kalevalaa että osallistuu sen sisältöjen kuljettamiseen ajassa eteenpäin mahdollistamalla uusien kohderyhmien vaivattomamman pääsyn Kalevala-aineksen äärelle. Samalla, kun ne selittävät Kalevalan synnyn toisin, lukija joutuu vertaamaan tarinamaailman versiota siihen, mitä itse on oppinut runonkeruusta, Lönnrotista ja suomalaisesta mytologiasta. Kalevala-muunnelmat myös painottavat fiktion keinoin rakenteellaan merkityksiä, jotka folkloristisessa tutkimuksessa on todettu faktaksi ja jotka ovat levinneet yleissivistykseksi. Yksi on käsitys siitä, että Kalevala on Lönnrotin taiteilijantyön tulos ja vain yksi mahdollinen versio, jonka samasta aineistosta olisi voinut koostaa. Edelleen, Kalevalan tarina ei ole historiallisesti totta tai edes yhtenäinen tarina, jonka kansanrunoudesta saattoi poimia ja kirjoittaa auki, kuten Kalevalan ilmestymisaikoina siihen suhtauduttiin. Nykytiedon korostaminen on tietoinen valinta Kalevala-muunnelmia voisi yhtä hyvin koostaa myös siten, että ne tukisivat toisenlaista, vanhempaa tietoa, tai aivan muunlaisia tavoitteita. Olisi kiinnostavaa verrata 1800-luvun lopun ja 1900-luvun alun Kalevala-muunnelmia tästä näkökulmasta 2000-luvun Kalevala-muunnelmiin, ja selvittää, missä määrin ne välittävät oman aikansa käsityksiä Kalevalasta.

Tarinamaailmoiltaan erilaiset Kalevala-muunnelmat kietovat oman maailmansa ja lukijan maailman yhteen ja siten tuottavat Kalevalan merkitykselliseksi kummassakin maailmassa. Kalevalan rooli suomalaisuuskäsityksen perustana olevassa kulttuurisessa muistissa muuttuu ja laajenee hiljalleen, kun Kalevala-muunnelmat ja muut löyhemmin kalevalaisia aineksia käyttävät esitykset tarjoavat yhä uusia yhteyksiä, joissa Kalevalan tarina on nykypäivän kannalta merkityksellinen. Keinot kiinnittää fiktiivinen tarinamaailma lukijan maailmaan ovat 
ainakin tarkastelluissa Kalevala-muunnelmissa varsin samankaltaisia riippumatta siitä, onko tarinamaailma historiallinen vai fantastinen. Tämä viittaa siihen, että teosten olemus Kalevala-muunnelmana ja tavoite kuljettaa tietoutta Kalevalasta eteenpäin uusille kohderyhmille on teosten rakennetta ohjaavana hallitsevampi kuin olemus historiallisena tai fantasiakirjallisuutena. Tämän artikkelin metodologian avulla ei päästä käsiksi yksittäisten tekijöiden motiiveihin valita Kalevala teostensa lähtökohdaksi, mutta kaikissa tarkastelluissa Kalevala-muunnelmissa todentuva tavoitteellinen nykymaailman ja Kalevalan maailman yhteenkietominen antaa olettaa, että nykykulttuurissamme on tarve toisaalta löytää Kalevalasta jotain uutta ja toisaalta säilyttää se osana suomalaista kulttuuria. Tämän artikkelin kohdeteoksena on kolme Kalevala-muunnelmaromaania, mutta on mahdollista, että kyseessä on laajempi ilmiö nykykulttuurin tavassa hyödyntää Kalevalaa ja kansanperinnettä. Tarkastelun arvoista voisi olla, löytyykö vastaavia maailmarakenteita myös muista teoksista laajassa Kalevala-muunnelmien joukosta, ei pelkästään romaaneista vaan esimerkiksi sarjakuvista tai laululyriikasta, ja onko kyse ylipäätään vain Kalevala-muunnelmia koskevasta ilmiöstä, vai toistuvatko rakenteet muidenkin eeposten muunnelmissa.

\section{Aineisto}

Hietikko, Harri V. 2005. Roger Repo ja tuonen väki. Kertomuksia yksityisetsivä Roger Revon omituisista toimeksiannoista. Tampere: Sanasato.

Koskinen, J. P. 2018. Kalevanpoikien kronikka. Helsinki: WSOY.

Lönnrot, Elias. (1849) 2004. Kalevala. Helsinki: Like.

Lönnrot, Elias. (1835) 1999. Kalevala taikka vanhoja Karjalan runoja Suomen kansan muinoisista ajoista. Helsinki: Suomalaisen Kirjallisuuden Seura.

Lönnrot, Elias. (1840) 2000. Kanteletar elikkä Suomen kansan vanhoja lauluja ja virsiä. Helsinki: Suomalaisen Kirjallisuuden Seura.

Parvela, Timo. 2008. Tuliterä. Helsinki:Tammi.

Parvela, Timo. 2009. Tiera. Helsinki: Tammi.

Parvela, Timo. 2009. Louhi. Helsinki: Tammi.

Ruusuvuori, Juha. 1999. Lemminkäisen laulu. Helsinki,: WSOY.

Sinisalo, Johanna. 2003. Sankarit. Helsinki:Tammi.

Vilén, Seija. 2012. Pohjan akka. Helsinki: Avain.

\section{Kirjallisuus}

Ahola, Elli-Mari. 2018. "Kertoja ja sisäistekijä maailmanrakentajina Jari Tammen Kalevalamuunnelmaromaanissa Kalevan solki." Kirjallisuudentutkimuksen aikakauslehti Avain 2/2018: 58-75. https://doi.org/10.30665/av.73020

Ahola, Elli-Mari. 2020. "Kansalliseepos fantasian ja arkimaailman välillä. Kalevalamuunnelmien maailmat 2000-luvulla". Teoksessa Tuolla puolen, siellä josskin. Käsityksiä kuvitelluista maailmoista, toimittaneet Ulla Piela ja Petja Kauppi, 147-166. Helsinki: Suomalaisen Kirjallisuuden Seura.

Ahola, Elli-Mari. 2021a. "Metalepsis horjuttaa ja sisäistekijä vakauttaa kerronnan ja tarinamaailman rakenteita Kalevala-muunnelmassa Pohjan akka." Kirjallisuudentutkimuksen aikakauslehti Avain 1/2021: 6-21. https://doi.org/10.30665/ $\underline{\text { av.95446 }}$ 
Ahola, Elli-Mari. 2021b. "Viisinkertainen Kalevala yksissä kansissa - viittausten kerrostuminen romaanissa Väinämöisen vyö." Sananjalka 2021: 173-192. https://doi.org/10.30673/ sja.99102

Allen, Graham. 2011. Intertextuality. Second edition. New York ja Lontoo: Routledge. https:// doi.org/10.4324/9780203829455

Anttonen, Pertti. 2005. Tradition through Modernity. Postmodernism and the Nation-State in Folklore Scolarship. Helsinki: Suomalaisen Kirjallisuuden Seura. https://doi.org/10.21435/ sff.15

Apo, Satu. 2004. "Laulaen vai kirjallisesti luoden? Uuden Kalevalan valmistusprosessi Elias Lönnrotin kuvaamana". Teoksessa Kalevala ja laulettu runo, toimittaneet Anna-Leena Siikala, Lauri Harvilahti ja Senni Timonen, 273-298. Helsinki: Suomalaisen Kirjallisuuden Seura.

Attebery, Brian. 2014. Stories about Stories. Fantasy and the Remaking of Myth. Oxford ja New York: Oxford University Press.

Fewster, Derek. 2006. Visions of Past Glory. Nationalism and the Construction of Early Finnish History. Helsinki: Suomalaisen Kirjallisuuden Seura.

Genette, Gerard. 1982. Structuralism and Literary Criticism. New York: Columbia University Press.

Gottelier, Lena. 2020. Uuden laulun aika. Suomenkielisen nykyrunouden yhteydet kansanrunoustraditioon. Turku: Turun yliopiston julkaisuja. http://urn.fi/ URN:ISBN:978-951-29-7946-2

Hallila, Mika. 2006. Metafiktion käsite. Teoreettinen, kontekstuaalinen ja historiallinen tutkimus. Joensuu: Joensuun yliopisto. http://urn.fi/URN:NBN:fi:ELE-1360849

Hatavara, Mari. 2007. Historia ja poetiikka Fredrika Runebergin ja Zacharias Topeliuksen historiallisissa romaaneissa. Helsinki: Suomalaisen Kirjallisuuden Seura.

Hatavara, Mari. 2010. Historia kuvina, jälkinä ja esityksinä Leena Landerin Käskyssä. Tampere: Tampereen yliopistopaino. http://urn.fi/URN:ISBN:978-951-44-9404-8

Hatavara, Mari. 2012. “Contested History, Denied Past. The Narrator's Failure in Ralf Nordgren's Det har aldrig hänt (1977)." Teoksessa Disputable Core Concepts of Narrative Theory, toimittaneet Göran Rossholm ja Christer Johansson, 83-98. Bern: Peter Lang. https:// doi.org/10.3726/978-3-0351-0394-6

Hatavara, Mari. 2014."Historical Fiction: Experiencing the Past, Reflecting History." Teoksessa True Lies Worldwide: Fictionality in Global Contexts, toimittaneet Anders Cullhed ja Lena Rydholm, 241-257. Berliini: DeGruyter. https://doi.org/10.1515/9783110303209

Heiskanen, Ulla, Hämäläinen, Niina, Mettomäki, Sirkka-Liisa, Saarelainen, Juhana, Tikkanen Laura. 2020. Matkalla Kalevalaan -oppimisaineisto. Helsinki: Suomalaisen Kirjallisuuden Seura. https://matkallakalevalaan.finlit.fi.

Hietasaari, Marita. 2015. "Postmodernist Warfare. Lars Sund's Siklax Trilogy". Teoksessa Novels, Histories, Novel Nations. Historical Fiction and Cultural Memory in Finland and Estonia, toimittaneet Linda Kaljundi, Eneken Laanes ja Ilona Pikkanen, 298-321. Helsinki: Suomalaisen Kirjallisuuden Seura. https://library.oapen.org/bitstream/id/5193400c2cc8-47c7-aba3-4c28552a5a2f/641488.pdf

Honko, Lauri. 1987. "Kalevala eeposten kuvastimessa". Teoksessa Kalevala ja maailman eepokset, toimittanut Lauri Honko, 10-20. Helsinki: Suomalaisen Kirjallisuuden Seura.

Hutcheon, Linda. (1980) 2014. Narcissistic Narrative. The metafictional paradox. With new preface. Waterloo: Wilfrid Laurier University Press.

Hutcheon, Linda. 1988. A Poetics of Postmodernism. History, Theory, Fiction. New York ja Lontoo: Routlegde. https://doi.org/10.4324/9780203358856 
Hutcheon, Linda. (1989) 2002. Politics of Postmodernism. Lontoo ja New York: Routledge. https://doi.org/10.4324/9780203426050

Hämäläinen, Niina, Holopainen, Reeta, Luhtala, Marika, Saarelainen, Juhana ja Sykäri, Venla. 2019-2021. Avoin Kalevala. Kansalliseepoksen digitaalinen, kriittinen editio. Osat I-III. Helsinki: Suomalaisen Kirjallisuuden Seura. http://kalevala.finlit.fi

Kaljundi, Linda, Laanes, Eneken, Pikkanen, Ilona. 2015. "Introduction. Historical Fiction, Cultural Memory and Nation Building in Finland and Estonia."Teoksessa Novels, Histories, Novel Nations. Historical Fiction and Cultural Memory in Finland and Estonia, toimittaneet Linda Kaljundi, Eneken Laanes ja Ilona Pikkanen, 26-76. Helsinki: Suomalaisen Kirjallisuuden Seura. https://library.oapen.org/bitstream/id/5193400c-2cc8-47c7-aba34c28552a5a2f/641488.pdf

Kaukonen, Väinö. 1956. Elias Lönnrotin Kalevalan toinen painos. Helsinki: Suomalaisen Kirjallisuuden Seura.

Kaukonen, Väinö. 1979. Lönnrot ja Kalevala. Helsinki: Suomalaisen Kirjallisuuden Seura.

Korpua, Jyrki. 2017. Lajivirren laulamaa. Kalevala ja kirjallisuus. Vantaa: Avain.

Leppälahti,Merja.2015."Myyttisestä fantasiaksi-Etsivät matkalla Pohjolaan."Fafnir2/4:42-53. http://journal.finfar.org/articles/myyttisesta-fantasiaksi-etsivat-matkalla-pohjolaan/

McHale, Brian. 2018. "Speculative Fiction, or, Literal Narratology." Teoksessa The Edinburgh Companion to Contemporary Narrative Theories, toimittaneet Zara Dinnen ja Robyn Warhol, 318-331. Edinburgh: Edinburgh University Press.

Mäkelä, Heidi Henriikka. 2021. "The Desired Darkness of the Ancient: Kalevala-Metric Poetry, Medievalism, and Cultural Memory in the Books Niemi and Viiden meren kansa." Mirator 21(1): 24-49.

Nikolajeva, Maria. 1988. The magic code. The use of magical patterns in fantasy for children. Tukholma: Almqvist \& Wiksell International.

Nünning, Ansgar. 2005. "Historiographic Metafiction." Teoksessa Routledge Encyclopedia of Narrative Theory, toimittaneet David Herman, Manfred Jahn ja Marie-Laure Ryan, 216. Lontoo ja New York: Routlegde. https://doi.org/10.4324/9780203932896

Nünning, Vera. 2010. "The Making of Fictional Worlds: Process, Features and Functions." Teoksessa Cultural Ways of Worldmaking: media and narrative, toimittaneet Ansgar ja Vera Nünning sekä Birgit Neumann, 215-244. Berliini: De Gruyter. https://doi. org/10.1515/9783110227567

Knuuttila, Seppo, Pekka Laaksonen ja Ulla Piela. 2008. "Alkusanat". Teoksessa Kalevalan kulttuurihistoria, toimittaneet Ulla Piela, Seppo Knuuttila ja Pekka Laaksonen, vii-xi. Helsinki: Suomalaisen Kirjallisuuden Seura.

Pitkäsalo, Eliisa. 2009. Sankareita ja tarinoita. Kalevalaiset henkilöhahmot Johanna Sinisalon romaanissa Sankarit. Jyväskylä: Jyväskylän yliopisto. http://urn.fi/ URN:ISBN:978-951-39-3786-7

Polvinen, Merja. 2012. "Being Played: Mimesis, Fictionality and Emotional Engagement." Teoksessa Rethinking Mimesis. Concepts and Practices of Literary Representation, toimittaneet Saija Isomaa, Sari Kivistö, Pirjo Lyytikäinen, Sanna Nyqvist, Merja Polvinen ja Riikka Rossi, 93-112. Newcastle upon Tyne: Cambridge Scholars Publishing.

Polvinen, Merja. 2018. "Sense-Making and Wonder: An Enactive Approach to Narrative Form in Speculative Fiction." Teoksessa The Edinburgh Companion to Contemporary Narrative Theories, toimittaneet Zara Dinnen ja Robyn Warhol, 67-80. Edinburgh: Edinburgh University Press.

Rigney, Ann. 2004.“Portable Monuments: Literature, Cultural Memory, and the Case of Jeanie Deans." Poetics Today 25:2. 361-396. dx.doi.org/10.1215/03335372-25-2-361 
Roine, Hanna-Riikka. 2016. Imaginative, Immersive and Interactive Engagements. The rhetoric of worldbuilding in contemporary speculative fiction. Tampere: Tampereen yliopisto. http://urn.fi/URN:ISBN:978-952-03-0195-8

Ryan, Marie-Laure. 1991. Possible Worlds, Artificial Intelligence and Narrative Theory. Indiana: University Bloomington \& Indianapolis Press.

Ryan, Marie-Laure. 2001. Narrative as Virtual Reality - Immersion and Interactivity in Literature and Electronic Media. Baltimore ja Lontoo: The John Hopkins University Press.

Ryan, Marie-Laure. 2008. "Transfictionality across Media." Teoksessa Theorizing Narrativity, toimittaneet John Pier ja Jose Angel Garcia Landa, 385-418. Berliini ja New York: De Gruyter. https://doi.org/10.1515/9783110969801.385

Ryan, Marie-Laure. 2015. "Transmedia Storytelling: Industry Buzzword or New Narrative Experience?" StoryWorlds 7(2): 1-19. https://doi.org/10.5250/storyworlds.7.2.0001

Saarelainen, Juhana. 2019. Runous, tieto ja kansa. Elias Lönnrotin ajattelu ja toiminta aikalaisfilosofian kontekstissa. Turku: Turun yliopiston julkaisuja. http://urn.fi/ URN:ISBN:978-951-29-7650-8

Sallamaa, Kari. 2010. "Rauta-aika ja kylmät myllyt. Kalevala sanataiteessa 1972-2009." Teoksessa Kalevalamittaisen runon tulkintoja, toimittaneet Seppo Knuuttila, Ulla Piela ja Lotte Tarkka, 355-368. Helsinki: Suomalaisen Kirjallisuuden Seura.

Siikala, Anna-Leena. 1992. Suomalainen samanismi. Mielikuvien historiaa. Helsinki: Suomalaisen Kirjallisuuden Seura.

Siikala, Anna-Leena. 2012. Itämerensuomalainen mytologia. Helsinki: Suomalaisen Kirjallisuuden Seura.

Sinisalo, Johanna. 2004. "Fantasia lajityyppinä ja kirjailijan työvälineenä." Teoksessa Fantasian monet maailmat, toimittaneet Kristian Blomberg, Irma Hirsjärvi ja Urpo Kovala, 11-31. Helsinki: BTJ Kirjastopalvelu.

SKVR-tietokanta. Helsinki: Suomalaisen Kirjallisuuden Seura. https://skvr.fi/

Tammi, Pekka. 1991. "Tekstistä, subtekstistä ja intertekstuaalisista kytkennöistä." Teoksessa Intertekstuaalisuus. Suuntia ja sovelluksia, toimittanut Auli Viikari, 59-103. Helsinki: Suomalaisen Kirjallisuuden Seura.

Tarkka, Lotte. 2005. Rajarahvaan laulu. Tutkimus Vuokkiniemen kalevalamittaisesta runokulttuurista 1821-1921. Helsinki: Suomalaisen Kirjallisuuden Seura.

FM Elli-Mari Ahola on Tampereen yliopiston väitöskirjatutkija. Hänen Suomen kirjallisuuden alan tutkimuksensa käsittelee kerronnan ja maailmojen rakenteita 2000-luvun Kalevala-muunnelmaromaaneissa, ja sitä on tehty osittain Suomalaisen Kirjallisuuden Seuran Pentti ja Eeva Lylyn rahaston ja Suomen Kulttuurirahaston Satakunnan rahaston tuella. 